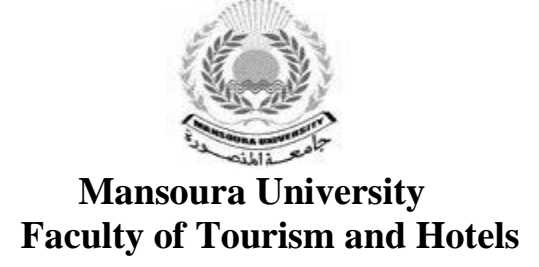

\title{
Plates and Portion size as a Factor DETERMINING FoOd CONSUMPTION IN BUFFET SERVICE \\ "A PRELIMINARY EMPIRICAL STUDY
}

\author{
By \\ Dr/ Sameh Gamal Saad \\ Faculty of Tourism and Hotel \\ Management - Helwan University
}

\section{RESEARCH JOURNAL OF THE FACULTY OF TOURISM AND HOTELS MANSOURA UNIVERSITY}

ISSUE NO. 11 (PART 1), JUNE. 2022 
Plates and Portion size as a Factor Determining Food Consumption in Buffet Service "A preliminary Empirical Study" 


\section{Plates And Portion size as a FaCtor DETERMINING FOOD CONSUMPTION IN BUFFET SERVICE \\ "A PRELIMINARY EMPIRICAL STUDY" \\ By Sameh Gamal Saad and Mahmoud Nabil Abdel-Ghafar}

Faculty of Tourism and Hotel Management - Helwan University

\section{Abstract:}

Food waste occurs at various levels of the food supply chain, from food production to food consumption. These are such as cooking, errors, excessive trimmings and cuts, overproduction, incorrect food storage, incorrect portion control, unacceptable of menu by the client, the inefficiency of the type of service used. Buffet service generally has more food waste. The present experiment illustrates that the availability of smaller dishes, and bowls in the buffet, or small food portions presented to customers resulted in reducing food waste. This was concluded by conducting two rounds of lunch buffet, arranged to feed 20 participants using different sizes of plates, bowls, food and drink portions in each round. The use of small equipment and food portions reduced considerably the amount of food waste obtained. Expressing these differences on money base would motivate the hotel to conduct the strategy of offering smaller portions when buffet service is used. 
Key words: Food consumption, food waste, portion size, buffet service

\section{Introduction:}

Managing restaurants is a complex task requiring more than a knowledge of food preparation and serving. Food and beverage managers are responsible for product planning, production, marketing, finance, personnel, purchasing, safety and security, and many operating functions. Restaurant managers are responsible, in particular, for work performance inside the dining area. While the control of all aspects of commodities and equipment is critical for a successful catering operation, the food portion and waste management are absolutely vital issue facing the restaurants and hotels to make the catering operation job worthwhile. It is very important that the costing of a dish and its selling price, with relation to its production price is accurately arrived at. For buffet restaurants, a small change can have a large impact on food waste, among these changes, a restaurant that uses large plates, its wastes are $135 \%$ more food than a restaurant that uses smaller plates, and this was mentioned by Wansink \& Payne (2008). Also such findings are confirmed by Pirani \& Arafat (2016) and Rasel (2020).

There are a number of food and beverage service methods. It should be remembered that food and beverage service is that part of the catering operations the customer actually sees and it is often, therefore, this aspect of a restaurant that 
can make or more an establishment's reputation. There are different factors should be considered to well manage food waste in catering industry in general and in buffet service in particular. Several researchers indicated the factors leading to minimizing the food waste in the catering operation (Bond 1964; Vilarino et al., 2017).

\section{These factors can be summarized in the following:}

- Proper purchasing

- Proper handling

- Proper preparation

- Proper storage

- Better menu planning

- Effective training of employees

- Reward employees for ideas resulting in reduced costs of food waste

- Good portion control at the time of service

As mentioned by Martinsen (2012), portion loss is an important challenge facing the catering industry. The main reason for this loss is that either the kitchen or service staff has not been trained to give the correct portions for each dish or that the management has not provided the right equipment, containers or dishes for the food service. Incorrect portion control affects the catering operation and increases the food cost due to the increase of food waste whether as unused food items on the buffet (left-over) or a remained amounts and scrapes of food from the consumers' 
dishes. This phenomenon is seen in hotels in general and in resort hotels in particular. This because the catering outlets in the resorts are usually seen as part of the entertainment facilities of the hotel. In these establishments the food and beverage services offered by the hotel have a different role because of guest's length of stay and particular attention should therefore be paid to such aspects of the operation as menu variety. Also, this phenomenon is apparent in such hotels because large numbers of people are catered as in the case of the Red Sea resorts, as a remote area, where there are not enough skilled and motivated staff to exercise good control and supervision (Bond, 1964) .

Consumed large portion by the customer instead the normal portion size will be reflected in the restaurant's gross profit particularly so if this is occurring with a number of menu items (Kasavana, 1984). Beverage portion can be controlled through using automatic beverage dispensing machines or through aiding by a control-conscious waiters, in other words a waiter himself serves the beverages. This similar to the case of carvery service, when the main course is selected from the carvery counter and served by a control conscious chef (Bond, 1964).

Buffet service is usually used in the resort hotels this service enables the hotel to feed large number of persons in a given time with less staff requirements. Compared with other types of food service, however, the buffet method can 
have a higher food cost, this is because good displays of food must be given which often involve presenting fairly large quantities of the items (Taylor, 1983). Therefore, a great consideration should be given to conduct standard portion sizes. A standard portion is the quantity of a particular food item that will be served to the customer; the quantity may be measured in terms of grams, or a numerical quantity

(Oteng-Ababio, 2014). The portion sizes of the food items are determined by management in conjunction with the heads of both the kitchen and restaurant departments. Similar findings have been reported by Pirani and Arafat (2015), they found that the waste from serving dishes was found to be very significant for many of buffet events. They believed that this type of waste needs to be implemented, from both the perspective of hotel staff and the perspective of guests (Martin-Rios, 2018).

\section{Materials and Methods:}

\section{The case study research method:}

The essence of this research is conducting a preliminary empirical study to illustrate the impact of food portion size on the food consumption in buffet service, since this factor considerably affects the amount of food waste. As indicating by Moyser and Wagstaffe (1987), this method as a case study as an empirical inquiry investigates a contemporary phenomenon within its real-life context, 
when the boundaries between phenomenon and context are not clearly evident. And this method is mostly appropriate when a researcher is seeking the answers to "how" and "why" questions.

\section{Buffet set-up:}

Based upon the popular food items used in the Egyptian resorts, mainly in Sharm El Sheikh and Hurghada hotels, certain dishes with different portions were selected to be tested on a lab scale i.e, in the experimental kitchen and restaurant of the Faculty of Tourism \& Hotel Management, Helwan University. The food items and drinks were prepared in enough amounts to meet the feeding of more than 20 panelists to avoid replenishment of the buffet. The panelists were selected from the faculty's members. They have been informed in advance that they are going to conduct an organoleptic test designed to evaluate the skills of some chefs submitting for recruiting in hotels. The panelists were requested to estimate the quality of food in each section of the buffet during having their lunch. The test will be conducted twice within two successive days in the faculty's restaurant. They were asked to rate the food quality on a scale of Excellent, good, fair, poor, and very poor. A scale of 5 "excellent" to 1 "very poor" was used to evaluate the degree of likeness and acceptability of the offered items on attributes of general appearance, flavor, 
color, texture. A table is designed to be used as a score sheet and judging scale for the investigation.

The food items were prepared in the same day of test, just before the start of having lunch. This took a few hours for preparation in the faculty's kitchen. It should be mentioned that the items were prepared with one chef and his assistants using the same amounts and adopting the same recipes during the two rounds of test. The organoleptic test was run in the faculty's restaurant, in a separate partition under common environment during the two days of investigation. The period of lunch was limited to one hour.

The buffet items were weighed or counted before having the lunch. After the accomplishment of lunch the unused quantities of food on the buffet as well as the remains and scrapes of food from the participants' dishes were weighed or counted. This was adopted in each round.

\section{To achieve the purpose of the study the following was adopted:}

\section{In the first Day:}

- Large plates and bowls were used.

- The bread, cake, tomato, cheese, meat were divided into large portions.

- Drinks of large size.

\section{In the second day:}

- Small size plates and bowls were used. 
- The bread, cake, tomato, cheese, meat were divided into small portions.

- Drinks of small size.

In the case of the second lunch i.e with small plates, it should be mentioned that the buffet was provided by limited number of the small dishes at the buffet. This was followed to ensure that the strategy of reducing the size of the dishes would be effective. After each lunch the evaluation sheets were collected by the researchers and of course neglected. The food and drink items used are shown in the tables of the following section "Results and Discussion"

\section{Results and Discussion:}

As mentioned in the methodology, two lunch buffets were arranged to feed 20 participants of faculty members and their assistants to investigate the importance of using small dishes and food portions as an impact leading to reduce the food waste. In the first buffet, large plates, bowls, food portions and drinks were used. Meanwhile in the second buffet, on the contrary, small plates, bowls, small food portion and drinks were considered. The similar quantities of the food items were weighed before having the launch. By ending the lunch the leftovers on the buffet or the remains and food scrapes from the participants' dishes were determined. This experiment would illustrate how the use 
مجلة كلية السياحة والفنادق - عدد 11 - يونيو 2022م.

of small plates and food portions affects the amount of food waste produced in the buffet service.

\section{Feature and units adopted in the comparison:}

\section{a. Starters :}

Bread : weighed in grams and served as large or small slices Cheese : weighed in grams and provided in large and small slices Stuffed white eggs : served in halves Tomato: weighed in grams and provided as slices Canapé: as pieces

Pickles: weighed in grams

\section{b. Main dishes:}

Fried potatoes, rice, peas and spinach were offered in shaving dishes after their weighing Meat balls weighed in grams and provided in large or small balls Roasted meat also weighed and served in large and small portion

\section{c. Dessert:}

English cake: weighed as slices large or small

Om Ali, weighed

Gaseous drinks: small or large cans 250, $350 \mathrm{ml}$

Fresh juice: small or large packs 225, $236 \mathrm{ml}$

\section{$\underline{\text { Measures of plates and bowls: }}$}


In the first round: plates of $30 \mathrm{~cm}$ diameter - bowls of $3.5 \mathrm{~cm}$ depth, $11.5 \mathrm{~cm}$ diameter

In the second round: plates of $24 \mathrm{~cm}$ diameter - bowls of $4.5 \mathrm{~cm}$ depth, $13.5 \mathrm{~cm}$ diameter

\section{Measures of drinks:}

In the first round: gaseous drinks (cans of $330 \mathrm{ml}$ ) - fresh juice (packs of $235 \mathrm{ml}$ )

In the second round: gaseous drink (cans of $250 \mathrm{ml}$ ) fresh juice (packs of 225ml)

Tables 1, 2, 3 and 4 state the data obtained from the two rounds of lunch arranged through two successive days on a lab scale.

Table (1): Quantities of food leftovers on the buffet after having the two rounds of lunch "Starters"

\begin{tabular}{|c|c|c|c|c|c|}
\hline \multirow{2}{*}{ Items } & \multirow{2}{*}{ Unit } & \multicolumn{2}{|c|}{ 1st round large } & \multicolumn{2}{c|}{ 2nd round small } \\
& & $\begin{array}{c}\text { Original } \\
\text { Quantities }\end{array}$ & $\begin{array}{c}\text { After } \\
\text { Lunch }\end{array}$ & $\begin{array}{c}\text { Original } \\
\text { Quantities }\end{array}$ & $\begin{array}{c}\text { After } \\
\text { Lunch }\end{array}$ \\
\cline { 3 - 6 } & & 1200 & & 1200 & \\
Bread & gm. & Large & 500 & Small & 750 \\
\hline
\end{tabular}




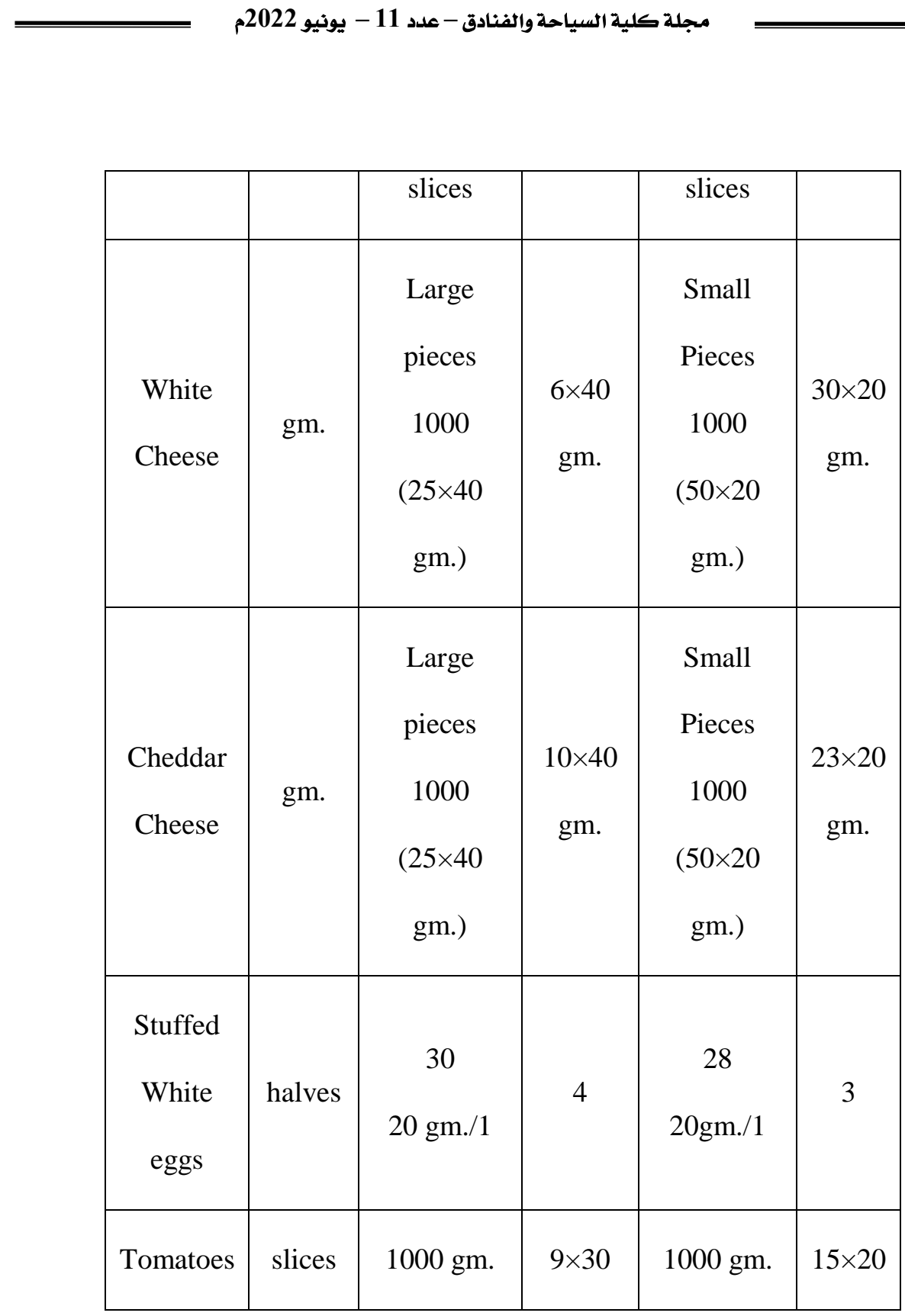


Plates and Portion size as a Factor Determining Food Consumption in Buffet Service "A preliminary Empirical Study"

\begin{tabular}{|c|c|c|c|c|c|}
\hline & & $33 \times 30 \mathrm{gm}$. & & $50 \times 20 \mathrm{gm}$. & \\
\hline \multirow{2}{*}{ Canapé } & pieces & $30 \mathrm{gm}$. & & 30 & \\
& & $15 \mathrm{gm} . / 1$ & 0 & $15 \mathrm{gm} . / 1$ & \\
\hline & & & & & \\
Pickles & gm. & $500 \mathrm{gm}$. & $120 \mathrm{gm}$. & $500 \mathrm{gm}$. & gm. \\
\hline
\end{tabular}

Table (2): Quantities of food leftovers on the buffet after having the two rounds of lunch "Main Dishes"

\begin{tabular}{|c|c|c|c|c|c|}
\hline \multirow{2}{*}{ Items } & \multirow{2}{*}{ Unit } & \multicolumn{2}{|c|}{$\begin{array}{c}\text { 1st round large } \\
\text { portions }\end{array}$} & \multicolumn{2}{|c|}{$\begin{array}{l}\text { 2nd round small } \\
\qquad \text { portions }\end{array}$} \\
\hline & & $\begin{array}{c}\text { Original } \\
\text { Quantities }\end{array}$ & $\begin{array}{l}\text { After } \\
\text { Lunch }\end{array}$ & $\begin{array}{c}\text { Original } \\
\text { Quantities }\end{array}$ & $\begin{array}{l}\text { After } \\
\text { Lunch }\end{array}$ \\
\hline $\begin{array}{c}\text { Fries } \\
\text { Potatoes }\end{array}$ & gm. & 1800 gm. & $\begin{array}{l}1100 \\
\text { gm. }\end{array}$ & 1800 gm. & $1350 \mathrm{gm}$. \\
\hline Rice & gm. & $5200 \mathrm{gm}$. & $\begin{array}{l}1200 \\
\text { gm. }\end{array}$ & $5200 \mathrm{gm}$. & $1500 \mathrm{gm}$. \\
\hline Peas & gm. & $5100 \mathrm{gm}$. & 2400 & $5100 \mathrm{gm}$. & $2800 \mathrm{gm}$. \\
\hline
\end{tabular}




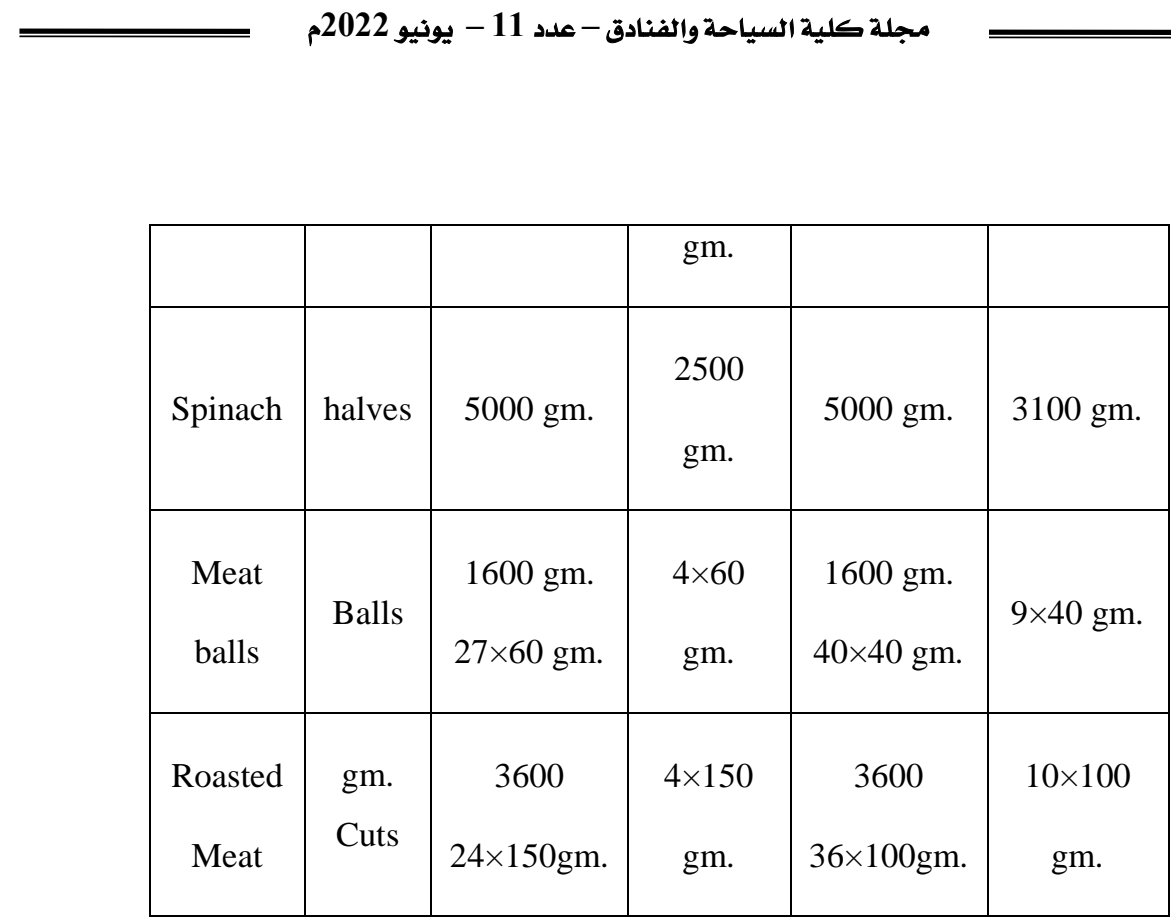

Table (3): Quantities of food leftovers on the buffet after having the two rounds of lunch "Desserts"

\begin{tabular}{|c|c|c|c|c|c|}
\hline \multirow{2}{*}{ Items } & \multirow{2}{*}{ Unit } & \multicolumn{2}{|c|}{$\begin{array}{c}\text { 1st round large } \\
\text { portions }\end{array}$} & \multicolumn{2}{|c|}{$\begin{array}{c}\text { 2nd round small } \\
\text { portions }\end{array}$} \\
\hline & & $\begin{array}{c}\text { Original } \\
\text { Quantities }\end{array}$ & $\begin{array}{l}\text { After } \\
\text { Lunch }\end{array}$ & $\begin{array}{c}\text { Original } \\
\text { Quantities }\end{array}$ & $\begin{array}{l}\text { After } \\
\text { Lunch }\end{array}$ \\
\hline $\begin{array}{c}\text { English } \\
\text { Cake }\end{array}$ & Slices & $\begin{array}{l}1000 \mathrm{gm} . \\
25 \times 40 \mathrm{gm} .\end{array}$ & $9 \times 40$ & $\begin{array}{l}1000 \mathrm{gm} . \\
50 \times 20 \mathrm{gm} .\end{array}$ & $25 \times 20$ \\
\hline
\end{tabular}




\begin{tabular}{|c|c|c|c|c|c|}
\hline Om Ali & & & & \\
Served & gm. & 4600 & 200 & 4600 & 300 \\
in bowls & & & & & \\
\hline Assorted & & Large size & 5 & 25 & 5 \\
gaseous & Cans & & & & \\
drinks & & small size & \\
\hline Assorted & & Large size & & small size & \\
fresh & Packs & & & & \\
juices & & & & & \\
\hline
\end{tabular}

Table (4): The food and drinks consumed during the two rounds of the lunch as percentages of the original quantities

\begin{tabular}{|l|c|c|}
\hline \multicolumn{1}{|c|}{ Items } & $\begin{array}{c}\text { 1st round } \\
\text { large } \\
\text { portions }\end{array}$ & $\begin{array}{c}\text { 2nd round } \\
\text { small } \\
\text { portions }\end{array}$ \\
\hline$\underline{\text { Starters }}$ Bread & $42 \%$ & $37.5 \%$ \\
\hline White Cheese & $76 \%$ & $50 \%$ \\
\hline Cheddar Cheese & $60 \%$ & $50 \%$ \\
\hline Stuffed White eggs & $87 \%$ & $89 \%$ \\
\hline
\end{tabular}




\begin{tabular}{|l|c|c|}
\hline Tomatoes & $73 \%$ & $70 \%$ \\
\hline Canapé & $100 \%$ & $100 \%$ \\
\hline Pickles & $76 \%$ & $66 \%$ \\
\hline $\begin{array}{l}\text { Main Dishes } \\
\text { Fries Potatoes }\end{array}$ & $38 \%$ & $30.5 \%$ \\
\hline Rice & $77 \%$ & $71 \%$ \\
\hline Peas & $53 \%$ & $45 \%$ \\
\hline Spinach & $50 \%$ & $38 \%$ \\
\hline Meat balls & $85 \%$ & $77.5 \%$ \\
\hline Roasted Meat & $83 \%$ & $72 \%$ \\
\hline $\begin{array}{l}\text { Desserts } \\
\text { English Cake }\end{array}$ & $64 \%$ & $50 \%$ \\
\hline Om Ali & $96 \%$ & $93 \%$ \\
\hline $\begin{array}{l}\text { Assorted gaseous } \\
\text { drinks (cans) }\end{array}$ & $80 \% *$ & $80 \% * *$ \\
\hline $\begin{array}{l}\text { Assorted fresh juices } \\
\text { packs) }\end{array}$ & $80 \% *$ & $80 \% * *$ \\
\hline
\end{tabular}

Tables 1, 2 and 3 state the original quantities of foods and drinks offered on the buffet as well as the leftover of these quantities obtained after having the lunch. It is fully clear that offering small portions whether using smaller serving equipment or providing smaller portions of foods and drinks affected markedly the quantities of the leftover on the buffet. The difference between the two rounds are clearly obvious with all items except with three items in the starters namely; stuffed white eggs, tomato slices, and canapé, where the differences were less pronounced .

Generally the amounts of items consumed during the first round i.e, the case of larger serving equipment or larger 
portions provided were noticeably greater than that noticed in the second round see Table 4 . The difference was slightly less with bread and Om Ali, where the difference here ranged only from $3 \%$ to $4.5 \%$ respectively. On the other hand the differences were pronounced with both types of cheese, pickles, spinach, roasted meat and cake. The difference reached $14 \%$ in the case of cake.

It should be noted that in the case of drinks either with gaseous drinks or fruit juices, the consumption was the same as number of consumed units, but it differed considerably if we accounted the consumption on the base of container size. In the first round larger cans and packs were provided, meanwhile in the case of the second round smaller cans or packs sizes were provided. This can be indicated by comparing the container size between the two rounds.

The noticeable increase in the amount of consumed items in the first round i.e using large portions ensures the importance of conducting the strategy of using smaller portions provision in the buffet service. This would be more pronounced when the expensive food items like meat dishes or Om Ali are considered. These findings are in a complete agreement with those of several authors (Kasavana, 1984; Pirani \& Arafat, 2014). 
It is advisable to put these differences before the food and beverage managers as well as the financial managers not only as an increase in the percentage of food and drink items consumed with the large portions but it should be expressed on the monetary basis. Here the money-based differences would give a more accurate comparison especially, when expensive items are considered

In respect to the food remains and scrapes from the participants' dishes, it was designed to state their amounts after the completion of each round. For this purpose all the food leftovers and scraps from. The used dishes were carefully collected and weighed. The obtained findings are as shown in Table (5).

\section{Table 5: Amount of Food Waste from the dishes}

\begin{tabular}{|l|c|c|}
\hline & $\begin{array}{c}\text { First round, } \\
\text { larger portion }\end{array}$ & $\begin{array}{c}\text { Second round, } \\
\text { smaller portion }\end{array}$ \\
\hline $\begin{array}{l}\text { Whole original food in } \\
\text { gm }\end{array}$ & 33650 & 33650 \\
\hline Waste, in gm & 757 & 579 \\
\hline Percentage & $22.5 \%$ & $17.25 \%$ \\
\hline
\end{tabular}

The above mentioned figures give another feature of comparison i.e, the amount of food waste obtained from the dishes expressed in grams and as a percentage from the whole amount offered on the buffet. These findings ensure that the use of large plates played a noticeable role in increasing the amount of waste produced from the used plates and bowls. Also using large portions of meat, cheese and tomato showed the same effect in increasing the 
leftovers and scrapes from the used dishes. The ratio reached $22.5 \%$ of the whole original amount, and reduced to $17.25 \%$ in the case of providing serving equipment and food portion of smaller sizes. Also for drinks the use of smaller containers reduced the amount of consumed drinks, in other words, reduced the drink cost by the difference between the price of larger containers and that of the smaller ones.

\section{Ethical consideration:}

Ethical responsibility is an important issue in the different activities in any society, particularly in the field of scientific research. In regards to the current research it is completely impossible to treat such issue i.e., studying the effect of plate size on the amount of consumed food by a person who is informed in advance about the purpose of the study and at the same time he is the judge. Another reason of adopting the current approach is that the researchers intended, from the accuracy point of view, to keep the same participants in the two rounds of test. However, mediating or overcoming this overlap or at least being accepted may be explained on the basis that all participants are researcher's colleagues and during the two days of test they were available and engaged in their own work in the faculty. Furthermore, it should be mentioned that the participants have been inquired that, regardless the panel test itself; it is an opportunity to have lunch together as a 
social event. However, such experiment can be conducted in the future, and repeated several times only with changing the size of plates used in a running restaurant and getting acceptable findings without facing any ethical obstacles.

\section{References}

- Bond L.E. (1964). "Factors to Consider in using Convenience Foods". Cornell Hotel and Restaurant Administration Quarterly, Vol.5, No1, pp. 4-5.

- Kasavana, M. (1984). How Can we Reduce Food Waste. Hotel and Restaurant International Journal, 18 (6), pp. 127-135.

- Martin-Rios, C., Demen-Meier, C., Gössling, S., \& Cornuz, C. (2018). "Food waste management innovations in the foodservice industry" Waste Management, 79, 196-206.

- Martinsen, J., Sundt, P., Kaysen, O., Kirkevaag, K., (2012). "Prevention of food waste in restaurants, hotels, canteens and catering" In: Nordic Council of Ministers, Tema-Nord, p. 537.

- Moyser, G. and Wagstaffe, M. (1987). Research Methods for Elite Studies. Political Science Journal, 35 (4), pp. 672-674.

- Oteng-Ababio, M. (2014). "Rethinking waste as a resource: insights from a low-income community in Accra, Ghana. City" Territory and Architecture, 1(1), pp.1-14. 
- Pirani, S. and Arafat, H. (2016). Reduction of Food Waste Generation in the Hospitality Industry. Journal of Cleaner Production, V.132 pp. 129-145.

- Rasel, K. (2020). Customers' Attitude toward Buffet Restaurant: A Study Conducted on Selected Buffet Restaurants in Dhaka City. NU Journal of Humanities, Social Sciences \& Business Studies, 6 (2), pp. 320-333.

- Taylor, S. (1983). Adjustment to Threatening Events: A theory of cognitive adaptation. American Psychologist, $38(11), 1161-1173$.

- Vilarino, M., Franco, C. and Quarrington, C. (2017). Food Loss and Waste Reduction as an Integral Part of a Circular Economy. Frontiers in Environmental Science, 10 (2), pp. 5-21

- Wansink, B., \& Payne, C. R. (2008). "Eating behavior and obesity at Chinese buffets" Obesity, 16(8), 1957-1960.

\section{حجم الطبق وقطع الغذاء كعامل محدد لاستهلاك طعام البوفيه: در اسة ميدانية عملية}

يحدث هدر الغذاء على مستويات مختلفة من سلسلة الإمداد الغذائي، من إنتاج الغذاء إلى استهلاك الغذاء. هذه منل الطهي، و الأخطاء، و التقطيع، و الإفراط في الإنتاج، و التخزين غير 
الصحيح للطعام، و التحكم غير الصحيح و عدم قبول العميل لقائمة الطعام، وعدم كفاءة نوع الخدمة المستخدمة. خدمة البوفيه بشكل عام بها فاقد طعام أكثر. توضح التجربة الحالية أن تو افر الأطباق الصغيرة ، و الأوعية في البوفيه ، أو أجزاء صغيرة من الطعام المقدمة للعملاء أدى إلى تقليل هدر الطعام. واختتم ذلك بإجر اء جولتين من بوفيه الغذاء ، تم ترتيهما لإطعام 20 مشاركًا باستخدام أحجام مختلفة من الأطباق والأوعية وأجزاء الطعام و الشراب في كل جولة. أدى استخدام المعدات الصغيرة و أجزاء الطعام إلى تقليل كمية النفايات الغذائية التي يتم الحصول عليها بشكل كبير - 